Volume 4 No. 1, Juni 2019

P ISSN 2442-594X | E ISSN 2579-5708

http://journal.iainlangsa.ac.id/index.php/tibyan

DOI: $10.32505 /$ tibyan.v4i1.786

\title{
POLITIK DAN PERUBAHAN PARADIGMA PENAFSIRAN AYAT-AYAT ALQURAN DALAM PROSES PILKADA DKI JAKARTA
}

\author{
Politics and Changes in the Paradigm of interpreting verses Of The Qur'an in The \\ Process of the Election of DKI Jakarta
}

\section{Lilik Ummi Kaltsum}

UIN Syarif Hidayatullah Jakarta

Jln. Ir. H. Juanda No. 95 Ciputat 15412, Indonesia

lilik.ummi@uinjkt.ac.id

\begin{abstract}
The Quranic verse which is believed has multi-interpretation and can be understood from many aspects of sciences frequently brings people who did not have any competency in this field interpreting it based on their own desire and purpose to win a specific group from another. The phenomenon of interpreting some of the Qur'anic verses by some groups in the process of a gubernatorial election in DKI Jakarta produces different interpretations. Finally, this differences cause conflict and debate which cannot be avoided. Every groups assume their interpretation is absolute. As a result, they blame or infidel another group. This research examines the interpretations of the Qur'anic verses which are used during a gubernatorial election in DKI Jakarta. The object of this study based on texts and audio which are spread on the sites of the internet. All of the data will be interpreted based on the theory of interpretation rules approach. This research concludes that the personal or group interest is able to change the paradigm of the Qur'anic interpretation including political interest.
\end{abstract}

Keywords: Qur'anic, tafsir, political, pilkada.

\begin{abstract}
Abstrak
Ayat Alquran yang diyakini memiliki multi-tafsir dan dapat dipahami dari berbagai aspek keilmuan sering menyeret orang-orang yang tidak kompeten untuk menafsirkan ayat sesuai dengan kepentingannya dan tujuan untuk memenangkan kelompok tertentu. Fenomena penafsiran beberapa ayat Alquran oleh beberapa kelompok-kelompok pada proses Pilkada DKI Jakarta melahirkan penafsiran yang berbeda pula. Perbedaan-perbedaan inipun pada
\end{abstract}


akhirnya memicu perseturuan dan perdebatan-perdebatan yang sulit dibendung. Masing-masing kelompok menganggap penafsiran yang paling absah sehingga menyalahkan atau bahkan mengkafirkan kelompok lain. Penelitian ini menelusuri penafsiran ayat-ayat Alquran yang digunakan selama Pilkada DKI Jakarta. Obyek penelitian dibatasi pada teks dan audio yang beredar di situs-situs internet. Data-data penelitian tersebut akan dibaca dengan pendekatan kaidah tafsir yang berlaku. Penelitian ini menghasilkan kesimpulan bahwa adanya kepentingan pribadi atau golongan dapat merubah paradigma penafsiran Alquran termasuk kepentingan politik.

Kata Kunci: Alquran, Tafsir, Politik, Pilkada.

\section{Pendahuluan}

Beberapa tahun yang lalu banyak kalangan membicarakan kasus penyebarluasan tafsir negatif di media sosial yang memanfaatkan momentum al-Mā'idah ayat 51 untuk DKI Jakarta. Fenomena ini berakibat munculnya persatuan ormas Islam di Indonesia untuk mengadakan gerakkan massa 411 [4 September 2016], 212 [2 Desember 2016] dan 313 [31 Maret 2017] yang juga dilegitimasi oleh pendapat salah satu ormas Islam dengan dikeluarkannya Fatwa MUI bahwa Basuki Tjahaja Purnama (Ahok) telah melakukan "penistaan atau penodaan agama." Awal muculnya gerakan itu adalah perdebatan tentang kepemimpinan non-Muslim yang menjadi tren sejak Ahok menjabat sebagai Gubernur DKI, dan semakin menghangat menjelang Pilkada DKI Jakarta 2017.

Mayoritas warga Muslim meyakini keharaman memilih non-Muslim sebagai pemimpin. Bagi mereka, larangan itu secara tegas termaktub dalam QS. al-Mā'idah ayat 51 dan banyak ayat lainnya. ${ }^{1}$ Akhirnya isu-isu agama pun ikut dimanfaatkan di dalamnya. Pernyataan salah satu kandidat petahana, ${ }^{2}$ Basuki Tjahaja Purnama (Ahok), di sebuah kesempatan menjadi pemicu. Pasalnya, Ahok melontarkan sebuah pernyataan berkaitan dengan penggunaan tafsir surat al-Mā'idah ayat 51. Oleh sebagian kalangan umat Islam, pernyataan tersebut dianggap sebagai penghinaan atas Alquran.

Fenomena aksi bela al-Mā'idah: 51 ini akhirnya menjadi berita yang terhangat di Indonesia. Uniknya, dalam persidangan Ahok, banyak dihadirkan saksi ahli, mulai dari ahli agama, hukum, tafsir, bahasa, psikolog dan lain sebagainya untuk membaca ulang kembali interpretasi berbagai pendekatan dari ayat tersebut. Bukan karena ayat tersebut merasa dizalimi atau karena peristiwa ini menjadikan agama dan politik selalu dikaitkan demi kepentingan tertentu. Dengan demikian, dimungkinkan ada perubahan paradigma penafsiran baik dilihat secara teks maupun konteks.

\footnotetext{
${ }^{1}$ Ahmad Khoirul Fata, M. Quraish Shihab dan Al-Maidah 51 (Gorontalo Post, 9/11/2016)

${ }^{2}$ (bahasa Inggris, incumbent) Petahana berasal dari kata "tahana", yang berarti kedudukan, kebesaran, atau kemuliaan dalam politik, adalah istilah bagi pemegang suatu jabatan politik yang sedang menjabat. Lihat Tim Penyusun, Kamus Besar Bahasa Indonesia (Jakarta: Balai Pustaka, 1990), cet. 3, h. 884.
} 
Belum selesai kontroversi atas kasus dugaan pelecehan agama yang dilakukan oleh Gubernur DKI Jakarta Basuki Tjahaja Purnama (Ahok), yang waktu itu, netizen dihehohkan dengan berubahnya tafsir Alquran surah al-Mà'idah ayat 51 yang dijual di toko-toko buku. Dalam tafsir tersebut, kata awliyā yang sebelumnya diartikan sebagai pemimpin atau wali, diubah menjadi teman setia. Akibatnya netizen merespons isu yang menjadi sangat viral di media sosial. ${ }^{3}$ Disamping kelompok anti Ahok ada juga kelompok pembela Ahok sehingga memperjuangkan untuk memenangkannya. Dalil yang dikemukakan adalah Indonesia bukan negara Islam tetapi Negara Pancasila dengan Bhineka Tunggal Ika. Disamping kedua kelompok itu, ada juga kelompok moderat, terlepas siapapun calon pemimpinnya, Islam tidak mengajarkan kekerasan, menghormati perbedaan dan harus bisa memberi kasih sayang, rasa aman antar sesama manusia (rahmat li al-‘ālaminn).

Berangkat dari fenomena di atas, dapat diulas bahwa selain karena Alquran sendiri memang sangat terbuka untuk ditafsirkan (multi interpretable), ${ }^{4}$ juga karena kitab-kitab tafsir sebagai suatu produk pemahaman, penjelasan, dan interpretasi (muntaj al-fikr) seorang mufasir terhadap teks Alquran ini sangat terkait dengan konteks sosio-kultural baik internal maupun eksternal penafsirannya. ${ }^{5}$ Dengan kata lain, karena tafsir dipengaruhi oleh tingkat kecerdasan (intelegensi) penafsir, keahlian atau latar belakang keilmuannya yang disebabkan berbeda penggunaan metode dan pendekatan dari masing-masing penafsir, konteks sosio-historis, dan bahkan oleh kepentingan serta ideologi mufasirnya. ${ }^{6}$ Fenomena ini menunjukkan bahwa kepentingan-kepentingan tertent $u$ dapat mempengaruhi paradigma penafsiran Alquran.

Di dalam Alquran tidak terdapat pembahasan soal politik. Ketika Nabi saw. wafat, beliau tidak memberikan arahan mengenai penggantinya dan bagaimana cara menggantinya. Beliau tidak memberikan nama pada negara Madinah yang dibentuknya. Dengan demikian, tidak ada dalil, baik qat'i maupun zanni $\bar{i}$ yang memerintahkan mendirikan negara Islam, karena Alquran tidak memiliki preferensi terhadap sistem politik yang mapan. ${ }^{7}$ Bukan berarti Alquran tidak menguraikan soal politik.

Kekuasaan politik yang diperoleh oleh seorang khalifah merupakan penganugerahan nikmat wewenang dari Allah untuk menetapkan keputusan-keputusan hukum dan kebijaksanaan, seperti tersirat dalam QS. al-Nisā' [4]: 58; "Dan apabila kamu menjatuhkan putusan di antara manusia, maka hendaklah kamu memutuskan

${ }^{3}$ http://datahakekat.blogspot.co.id/2016/10/menag-perubahan-tafsir-al-maidah-51.html

${ }^{4}$ Islah Gusmian, Khazanah Tafsir Indonesia; dari Hermeneutika hingga Ideologi (Yogyakarta: LKiS, 2013), h. 2.

${ }^{5}$ Abdul Mustaqim, Pergeseran Epistemologi Tafsir (Yogyakarta: Pustaka Pelajar. 2008). h. 21.

${ }^{6}$ Islah Gusmian, Khazanah Tafsir Indonesia, h. viii. atau M. Quraish Shihab, Membumikan Alquran: Fungsi dan Peran Wahyu dalam Kehidupan Masyarakat (Bandung: Mizan, 1995), h. 40.

${ }^{7}$ Said Agil Husin Al-Munawar, Dimensi-dimensi Kehidupan dalam Perspektif Islam (Malang: Pascasarjana Unisma, 2001), h. 82. 
dengan adil." Oleh karena itu, manusia yang baik, adalah yang memperhatikan kehendak pemberi nikmat wewenang itu. ${ }^{8}$

Dalam sejarah perang Shiffin yang mengisahkan kudeta politik kekhalifahan 'Ā̄i bin Abì Tāalib. Demi mengamankan kekhalifahannya, 'Āli memindahkan (Ibukota Negara) pusat pemerintahan dari Madinah ke Kufah, kemudian memberhentikan sebagian besar Gubernur yang diangkat oleh pendahulunya dan mengangkat pejabatpejabat lain. Namun, 'Āli tidak memperhitungkan Mu'awiyah, Gubernur Suriah dan kerabat 'Uthmān, karena kemudian Mu'awiyah bangkit melawan dan menuntun kematian 'Uthmān. Dengan taktik dan kecerdikannya, Mu'awiyah mempermainkan emosi umat Islam. Mu'awiyah tidak mau menghormati 'A $\bar{A} \bar{l}$, dan menyudutkannya pada sebuah dilema: menyerahkan para pembunuh 'Uthmān, atau menerima status sebagai orang yang bertanggungjawab atau pembunuhan itu, sehingga ia harus diturunkan jabatan khalifah. ${ }^{9}$

Dari peristiwa ini, kemudian berlanjut perang antara pasukan 'A Ali dan Mu'awiyah. 'Āli dikabarkan membawa pasukan sebanyak 50.000 orang dari Irak di bawah pimpinan Mālik al-Ashtār, dan Mu'awiyah membawa tentara Suriah di bawah pimpinan 'Amr ibn al-'Aṣ. Dalam peperangan ini, pasukan 'Āli hampir menang, karena kecerdikan 'Amr ibn al-'Aș melancarkan siasat. Ia meletakkan salinan Alquran di ujung tombak, sebuah tanda berakhirnya peperangan, dan kedua belah pihak yang bertikai melakukan arbitrase demi menyelamatkan jiwa umat Islam. Kedua pihak sepakat untuk memecat kedua pemimpin mereka, dan mengangkat wakilnya ' $\overline{\mathrm{A}} \overline{\mathrm{i}}, \mathrm{Ab \overline { \textrm {i } }}$ Mūsā al-Ash'āri dengan menetapkan Mu'awiyah sebagai khalifah. ${ }^{10}$ Peristiwa taḥkìm dalam perang Shiffin ini menunjukkan adanya penggunaan atau pemanfaatan ayat-ayat Alquran untuk golongan.

Kajian ini memang kasusnya sudah berlangsung atau tidak aktual lagi. Akan tetapi, kajian ini masih tetap menarik hingga sampai sekarang dengan mempertimbangkan beberapa hal: 1) Fungsi penafsiran terhadap Alquran harus berlandaskan pada Alquran sebagai hidayah bagi manusia bukan untuk menguatkan dukungan madzhab, ideologi, dan kekuatan politik. 2) Tafsir sangat terkait dengan konteks sosio-kultural baik internal maupun eksternal penafsirannya. Maka disadari atau tidak tafsir akan selalu dipengaruhi oleh latar keilmuan, situasi/kondisi sosiohistoris mufasirnya, bahkan sangat mungkin di dalamnya ada semacam hidden ideology dan kepentingan politis, maka dimungkinkan ada bentuk perubahan paradigma penafsiran. 3) Penafsiran-penafsiran yang diwarnai kepentingan politis ini, bukan hanya menampilkan Alquran dalam kerangka yang ambigu. Bahkan yang lebih telak, menjadikan Alquran menyimpang dari watak aslinya sebagai petunjuk hidup bagi manusia; menjadikan Alquran kehilangan elan vital-nya di dalam mengurai dan mencari penyelesaian atas problem-problem kehidupan dan sosial umat manusia.

\footnotetext{
${ }^{8}$ Said Agil Husin Al-Munawar, Dimensi-dimensi Kehidupan dalam Perspektif Islam, h. 79-80.

${ }^{9}$ Philip K. Hitti, History of The Arabs: From the Earliest Times to the Present, terj. R. Cecep Lukman Yasin dan Dedi Slamet Riyadi (Jakarta: PT Serambi Ilmu Semesta, 2008), h. 224-225.

${ }^{10}$ Philip K. Hitti, History of The Arabs, h. 226.
} 
Untuk mendapatkan informasi yang benar. Kajian ini mencoba menguraikan ayat-ayat Alquran yang banyak digunakan oleh masyarakat dalam proses Pilkada DKI Jakarta. Obyek penelitian terfokus pada teks dan audio yang beredar di situs-situs internet. Masalah utama perlu dijawab dalam kajian ini adalah tentang ayat-ayat yang digunakan untuk kepentingan politik sehingga mempengaruhi perubahan paradigma penafsiran Alquran. Penulis juga menegaskan bahwa mengingat banyaknya penafsiran yang dilakukan kurang tepat oleh sebagian orang, dapat menyesatkan kaum awam, jika semua itu tidak segera dianalisis ulang maka dikhawatirkan adanya konflik yang berkepanjangan disebabkan oleh oknum-oknum yang tidak bertanggung jawab.

\section{Multi-Tafsir Pada Teks Tunggal Alquran}

Dalam kajian ini memberi gambaran multi-tafsir dari berbagai kecenderungan bentuk penafsiran yang menyangkut ragam kepentingan dan bentuk relativisme penafsiran Alquran. Pertama, ragam kepentingan diuraikan Naṣr Hạamid Abū Zayd. Ia mengklaim bahwa penafsiran Alquran selama ini dipenuhi oleh kepentingankepentingan ideologis, serta metode interpretasi yang dipakai kalangan ulama selama ini tidak ilmiah. Menurutnya, pendekatan yang layak dan niscaya dilakukan adalah pendekatan kritik historis dan kritik sastra. ${ }^{11}$ Klaim Abū Zayd ini mengacu karya-karya tafsir ditulis berdasarkan pada mazhab mereka, di dalamnya menyusup bid'ah-bid'ah, seperti tafsir 'Abd al-Raḥmān bin Kaisan al-Asāmm, al-Jubbā'i, 'Abd al-Jabbār, alRummāni, al-Zamakhshari dan sebagainya. Kelompok-kelompok ini menetapkan dasar-dasar sesuai mazhab mereka anut yakni Mu'tazilah, karena menyimpang dari pendapat-pendapat sahabat, tabi'in dari penafsiran mereka, hal ini dapat dikatakan sebagai pelaku bid'ah. Selain itu, Abū Zayd juga membandingkan kitab tafsir yang lebih baik, ditulis dengan menyebutkan suatu pendapat (ulama) salaf atau riwayat dan juga bebas dari bid'ah, seperti tafsir Jarir al-Tabari, Tafsir Ibn 'Ațiyyah dan sebagainya. ${ }^{12}$

Tak jauh pendapat Abū Zayd mengenai penyimpangan dalam penafsiran, peneliti juga mengulas penyimpangan dalam penafsiran Alquran yang lebih dahulu dikemukan al-Dzahabī dalam buku Al-Ittijā-hat al-Munḩarifah fî Tafsìr al-Qur'ān al-Karīm, Dawāfi'uha, seperti al-Zamakhsharì ketika menafsirkan QS. al-An'ām [6]: 137: “... وكذالك زين " لكثير من المشركين قتل أو لادهم شركاؤهم "

Al-Zamakhsharì membenarkan dalam tafsirannya dengan dua macam qirā'at. Pertama, menurut qirā'at Hafs, dibaca (زَ) “zayyana” dalam bentuk aktif (mabni lil-

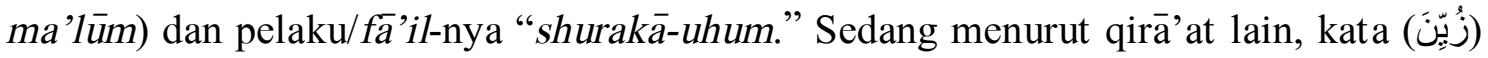
"zuyyina" dalam bentuk pasif (mabnī lil-majhū $)$, dan obyeknya adalah kata "qatla auladihim," sedangkan kata "shurakā-uhum" apabila dikaitkan dengan kata kerja (زَيَّ) “zayyana." Dari qirā'at tersebut, al-Dzahabī menganggap seakan-akan ada pertanyaan:

\footnotetext{
${ }^{11}$ Moch. Taufiq Rhidho, “Analisis Metode Kontekstual Naṣr Hamid Abū Zayd (Re-Interpretasi atas Konsep Asbab Al-Nuzul)", Rasail, Vol. 1, No. 4, 2015, h. 3.

${ }^{12}$ Nașr Hamid Abū Zayd, Mafhum al-Nāṣ Dirasah fì 'Ulūm al-Qur'ān, terj. Khoirun Nahdliyyin, Tekstualitas Alquran: Kritik terhadap Ulum Alquran (Yogyakarta: LKiS, 2005), h. 278.
} 
"Siapakah yang menyebabkan mereka menganggap baik?" Kemudian dijawab: "Yang menyebabkan adalah para pemimpin mereka."13 Kedua, al-Zamakshari menolak qirā'at

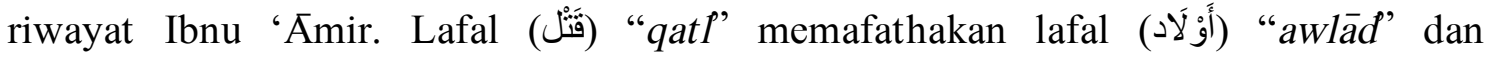
mengkasrahkan lafal (شُرَكَاء) “shurakā"," dengan mengidhafakan kata qatl kepada shurakä, dan memisahkan keduanya tidak dengan keterangan (darf) melaikan dengan maf'ūl (أَوْ لَادَهُمْ ) “awlādahum." Penjelasan seperti ini, menurut al-Dzahabỉ adalah salah. ${ }^{14}$

Al-Zamakhshari menolak qirā'at riwayat Ibn 'Āmir ini didasarkan atas pendapat mayoritas ahli Nahwu aliran Bashrah yang menyatakan tidak boleh memisahkan muḍāf dan muḍf ilaih kecuali dengan ḍaraf (keterangan). Masalah ini merupakan masalah kontroversial di kalangan ahli Nahwu. ${ }^{15}$

Untuk melengkapi argumen di atas, penulis menguraikan ragam kepentingan dalam penafsiran Alquran dalam situasi politik masa sahabat. Penulis mengulas artikel Muhsin Alhaddar yang menyinggung sahabat Abū Bakr al-Siddiq yang mengambil keputusan berdasarkan ijtihadnya guna menyelesaikan masalah umat. Misalnya, keputusan dalam memerangi kaum yang tidak membayar zakat. Hal ini didasari dari penafsiran Abū Bakr terhadap ayat-ayat Alquran demi menyerang lima kabilah (kabilah Abs, Zubyān, Banu Kinanah, Gatafan, dan Fazarah) yang enggan membayar zakat. Keputusan Abū Bakr bukan atas inisiatifnya sendiri, akan tetapi Abū Bakr menggunakan ayat Alquran pada QS. al-Baqarah ayat 23 sebagai siasat. ${ }^{16}$ Penafsiran dan tindakan Abū Bakr dapat dianggap ada kepentingan politik, akan tetapi upaya itu bukan atas dukungan kelompok tertentu, hanya saja penafsiran Abū Bakr ini tidak lain demi kemaslahatan umat. Karena jika hal ini dibiarkan, maka kabilah yang membayar pasti akan mengikuti kabilah yang tidak bayar zakat. ${ }^{17}$

Sebagaimana pembahasan di atas dalam sejarah perang Shiffin yang mengisahkan kudeta politik kekhalifahan 'Āli bin Abi Tạalib. Khawarij tampil dengan penafsirannya, pihak Mu'awiyah bin Abī Sufyān telah menggunakan Alquran demi kepentingan politik mereka pada saat terdesak dalam perang Shiffin, yaitu mengangkat Alquran sebagai strategi menghindari kekalahan dari pihak 'A $\bar{A} \overline{l i}$. Motif politik semacam ini tidak bisa disamakan dengan penggunaan Alquran oleh Khawarij dan pihak Mu'awiyah yang cenderung mengeksploitasi Alquran. ${ }^{18}$

Selain itu, penulisan tafsir sebagai bentuk dukungan dan perlawanan terhadap rezim Orde Baru. Dalam catatan Islah Gusmian terkait penulisan tafsir ditulis pada situasi perlawanan politik, seperti Faị̣ al-Raḥmān karya K.H. Saleh Darat. Karya tafsir ini tidak hanya bertujuan memberikan pemahaman tentang isi Alquran, tetapi

\footnotetext{
${ }^{13}$ Muhammad Husein al-Dzahabī, Penyimpangan-penyimpangan ...., h. 40-41.

${ }^{14}$ Muḥammad Husein al-Dzahabī, Penyimpangan-penyimpangan ...., h. 41.

${ }^{15}$ Muḥammad Husein al-Dzahabī, Penyimpangan-penyimpangan ...., h. 42.

${ }^{16}$ Muhsin Ali Alhaddar, Rasionalitas Penafsiran Sahabat dan Tabi'in "Kajian Atas Tafsir bi alMathur"(Ciputat: Isdar Press, 2012), h. 92.

${ }^{17}$ Muhsin Alhaddar, "Unsur Politik dalam Dunia Penafsiran Alquran: Kasus-Kasus Penafsiran Sahabat dan Aliran Teologi Islam" Rausyan Fikr, Vol. 10, No. 2 Juli-Desember 2014, h. 221.

${ }^{18}$ Mohammad Subhan Zamzami, Tafsir Ideologis dalam Khazanah Intelektual Islam, h. 165.
} 
dari sisi budaya juga merupakan bentuk perlawanan terhadap kolonial Belanda. ${ }^{19}$ Selain itu, al-Huda karya Bakri Syahid dan al-Iklil karya KH. Misbah Mustafa sebagai representasi sikap politik pada konteks sosial politik rezim Orde Baru. Bentuk dukungan Bakri Syahid pada praktik politik dan kebijakan Orde Baru ketika menjelaskan QS. Yūnus [10]: 7 sebagai asas Pancasila yang dibangun oleh rezim Orde Baru. ${ }^{20}$

Dukungan serupa ia paparkan ketika menjelaskan QS. al-Hujurāat [49]: 6-7; "Intelijen Negara lan Stabilitas Keamanan punika kuwajibanipun Pamarentah kabantu masyarakat. Suraosipun ayat: 6-7 punika manawi ing jaman modern kawastanan BAKIN utawi Badan Koordinasi Intelijen Negara wonten ing Tata Bina Pamarintahan Republik Indonesia. Wonten ing Negari Demokrasi, kados Negari kita, Negari Pancasila, hakekatipun Intelijen Negari lan stabilitas keamanan punika rumagangipun Rakyat ingkang kapimpin dening Pamarentah, lan intinipun kakiyatan ABRI “.... ${ }^{21}$

Penjelasan ayat di atas, nampak sangat mendukung posisi pemerintahan Orde Baru. Menurutnya, sangat penting koordinasi dan komunikasi antara para pemerintahan dengan bawahannya dan dengan masyarakat. Jadi stabilitas keamanan dalam suatu negara adalah tanggung jawab masyarakat yang dipimpin oleh pemerintah dan pada intinya terletak di kekuatan ABRI, ${ }^{22}$ yang waktu itu Soeharto sendiri sebagai mantan Panglimanya.

Penafsiran Bakri Syahid di atas dapat dilihat bagaimana kondisi keilmuan mufasir merupakan seorang militer dan latar belakang kehidupan sosialnya sangat mempengaruhi terhadap penafsirannya. Berbeda dengan Misbah Mustafa. Menurut Islah Gusmian, justru Misbah mengkontestasikan penolakan salah satu kebijakan rezim Orde Baru secara kritis. Di antaranya adalah terkait program Keluarga Berencana (KB). Sikapnya ini dikemukakan ketika ia menafsirkan QS. al-Qașaș [28]: 4. Ayat ini berbicara tentang kisah Fir'aun yang membunuh setiap bayi yang lahir berjenis kelamin laki-laki yang saat itu pertumbuhan penduduk Mesir dari keturunan Bani Isrā'il begitu cepat, sedangkan pertumbuhan penduduk dari golongan Qibțî, sebagai penduduk asli, sangat lambat. Kondisi itu membuat para elite politik di Mesir khawatir, karena kelak orang-orang keturunan Bani Israil akan mengambil alih kekuasaan. Kekhawatiran itu memuncak ketika pada suatu malam raja Fir'aun bermimpi melihat api besar yang berkobar-kobar membakar kerajaannya yang kemudian ditafsirkan oleh para ahli nujum ketika itu sebagai tanda akan terjadi kudeta kekuasaan. $^{23}$

\footnotetext{
${ }^{19}$ Islah Gusmian, "Tafsir Alquran Bahasa Jawa: Peneguh Identitas, Ideolog, dan Politik," Suhuf, Vol. 9, No. 1, Juni 2016, h. 157-158.

${ }^{20}$ Lihat Islah Gusmian, Tafsir Alquran Bahasa Jawa: Peneguh Identitas, Ideolog, dan Politik, h. 158.

${ }^{21}$ Bakri Syahid, al-Huda Tafsir Qur'an Basa Jawi (Yogyakarta: Bagus Arafah, 1983), h. 1033.

${ }^{22}$ Khusnul Arifah Ma'sum, "Konsep Pemerintahan Menurut Bakri Syahid: Studi atas Tafsir AlHuda Tafsir Qur'an Basa Jawi" (Skripsi: Jurusan Ilmu Alquran dan Tafsir Fakultas Ushuluddin dan Dakwah IAIN Suakarta, 2017), h. 70.

${ }^{23}$ Islah Gusmian, Tafsir Alquran Bahasa Jawa ...., h. 159. Atau lihat Misbah Zainul Mustafa, al-Iklil fi Ma'ani at-Tanzil, juz 20 (Surabaya: Toko Kitab Al-Ihsan, t.th), h. 370.
} 
Penjelasan latar historis di atas, Islah menganggap Misbah mengaitkannya dengan program KB yang dicanangkan oleh pemerintah Indonesia dengan memberikan penafsiran yang diterjemahkan Islah ke dalam bahasa Indonesia sebagai berikut: "Hal demikian itu terjadi lagi pada zaman sekarang. Raja dunia, yaitu Amerika dan Rusia berusaha mengurangi cepatnya pertumbuhan penduduk di kalangan umat Islam melalui Perserikatan Bangsa-Bangsa, kemudian berlaku di negara-negara seluruh dunia, termasuk Indonesia. Alasannya adalah bahan makanan yang tersedia tidak mencukupi kebutuhan penduduk, mengkhawatirkan jumlah pengangguran yang meningkat, dan hal lainnya." ${ }^{24}$ Penafsiran tersebut adalah bentuk penolakan Misbah dikaitkan dengan program KB (dua anak cukup) yang dilakukan atas kepentingan rezim Orde Baru tersebut.

Selain mereka di atas, bentuk kritik sosial dilakukan Syu'bah ketika menafsirkan QS. al-An'ām [6]: 65 yang dikaitkan dengan keganasan politik rezim Soerharto atas kecurigaan kepada Islam, yang sampai-sampai mengakibatkan pengekangan kegiatan dakwah, keharusan memperoleh izin atau menyerahkan teks resmi sebelum khutbah atau ceramah, aktivitas intel sampai ke dalam masjid dan lain sebagainya. ${ }^{25}$

Yang terakhir, kepentingan orientalis dalam penafsiran Alquran dalam mengkaji Islam dengan membawa misi; misi imprealisme, baik agama, budaya ataupun kepentingan politik. Seperti Theodor Noldeke termasuk kelompok orientalis yang menggugat orisinalitas dan otentisitas Alquran lewat pendekatan kritik sejarah dengan harapan untuk mengurangi peran dalam masyarakat. Sebagaimana usahanya, ia melacak hubungan dan analisis semantik mufradāt al-Qur'ān dengan kitab-kitab sebelumnya. ${ }^{26}$ Selain itu, Arthur Jeffery, ia anggap bahwa Alquran yang ada sekarang ini sebenarnya telah mengalami berbagai ta'rif yang dibuat 'Uthmān bin 'Affān, alḤajjāj ibn Yūsuf al-Thaqāầ dan Ibn Mujāhid. Menurut Jeffery, 'Uthmān membuat penyeragaman mushaf di berbagai wilayah kekuasaan Islam. Karena tindakan 'Uthmān tersebut didorong oleh motivasi politik, dengan menuduh al-Hajjāj bin Yūsuf alThāqafî telah membuat Alquran versi baru secara menyeluruh. ${ }^{27}$

Kedua, bentuk penafsiran kontemporer yang mengusung relativitas dalam menafsirkan Alquran. Salah satu tokoh penting yang mengusung relativitas tafsir adalah Naṣr Hamid Abū Zayd. Dengan wacana 'pembaruan'-nya ini, ia cukup dikenal di kalangan akademisi studi Islam di Indonesia, di samping Mohammed Arkoun, Muḥammad Shạ̣rūr, 'Abid al-Jābirì dan para pemikir liberal lainnya. Ia dijadikan sebagai rujukan penting, pemikiran-pemikirannya dipuja nyaris tanpa kritik, meski di

\footnotetext{
${ }^{24}$ Islah Gusmian, Tafsir Alquran Bahasa Jawa ...., h. 159.

${ }^{25}$ Syu'bah Asa, Dalam Cahaya Alquran: Tafsir Ayat-ayat Sosial Politik (Jakarta: PT Gramedia Pustaka Utama, 2000), h. 172-173.

${ }^{26}$ Hayat Hidayat dan Moh. Hidayat, Sejarah Alquran dalam Pandangan Theodor Noldeke [18361930] dalam Mohammad Anwar Syarifuddin, Kajian Orientalis terhadap Alquran dan Hadits (Ciputat: CV Sakata Cendikia, 2015), h. 35.

${ }^{27}$ Jamaluddin Zuhri, Athur Jeffery dan Kajian Sejarah Teks Alquran, h. 45.
} 
negara asalnya ia divonis murtad oleh pengadilan tinggi Mesir. ${ }^{28}$ Wacana yang dilakukan Abū Zayd dianggap membongkar keyakinan Umat Islam yang selama ini telah mapan. Ia berusaha menghilangkan sakralitas Alquran dengan anggapan Alquran sebagai produk budaya. ${ }^{29}$ Teks dianggap sebagai produk budaya dalam konteks Alquran, yaitu fase proses pembentukan dan kematangan, yaitu fase di mana teks setelah itu berubah menjadi produsen budaya, dalam pengertian bahwa teks tersebut menjadi teks yang hegemonik yang menjadi acuan dan landasan bagi teks-teks lain. ${ }^{30}$

Paham relativisme tafsir disambut keras Adian Husaini. Baginya pemahaman ini sangat berbahaya, sebab; menghilangkan keyakinan akan kebenaran dan finalitas Islam, menghancurkan bangunan ilmu pengetahuan Islam, menempatkan Islam sebagai agama sejarah yang selalu berubah mengikuti zaman, sejalan dengan arus liberalisasi Islam. ${ }^{31}$ Lebih tepatnya, mereka yang beranggapan paham relativisme tafsir sebagai wujud bahwa tidak ada lagi satu kebenaran yang bisa diterima semua pihak, semua manusia bisa salah. Pernyataan ini dikritik Adian Husaini, sampai-sampai ia menganologikan, bagaimana dengan Nabi, ijma' sahabat? Bukankah ada hadis Nabi yang menyatakan; “Umatku tidak akan bersepakat dalam kesatuan?" Apakah semua itu harus dibongkar dengan hermeneutika? Imām al-Bukhārì dan para ulama hadis lainnya banyak menyepakati tentang kesahihan dan kemutawatiran banyak hadis Nabi. Mereka menuangkan pemikiran mereka ke dalam kitab-kitab hadis, dari hasil akal pikiran mereka. Ketidaksetujuan Adian ini akibat konsep hermeneutika yang diuraikan Amin Abdullah yang dinyatakan bahwa semua produk tafsir adalah produk akal manusia, dan karena itu sifatnya pasti "terbatas," "parsial-kontekstual," dan "bisa saja keliru." Dengan demikian, menurut konsep hermeneutika tidak ada tafsir yang qat ' $\bar{i}$, tidak ada yang pasti kebenarannya, semuanya relatif, dan semuanya zanni.

Argumentasi Amin dikritik keras oleh Adian karena pendapat yang dilontarkan sangatlah tidak beralasan. Adian berpendapat bahwa Islam adalah agama yang satu, dan sepanjang sejarah ulama Islam bersatu dalam banyak hal. Tidak benar, akal manusia bisa menyakini yang satu. Para mufassir pun sepakat bahwa Nabi Muhammad saw adalah manusia, dan bukan Tuhan atau setengah Tuhan. Ada yang qat' $i$ dan ada yang zann $\bar{i}$ dalam penafsiran Alquran. Jadi apa yang dinyatakan Amin bahwa "semuanya adalah relatif." Padahal ucapannya itu sendiri bersifat relatif. ${ }^{22}$ Tidak dapat dibenarkan bahwa metode yang telah dirumuskan oleh ulama salaf tidak relevan lagi untuk diterapkan pada zaman sekarang.

\footnotetext{
${ }^{28}$ Makalah, Lalu Heri Afrizal, "Studi Kritik Atas Metodologi Tafsir Nașr Hamid Abū Zayd dan Dampaknya Terhadap Pemikiran Keagamaan" (Peserta Program Kaderisadi Ulama ISID Gontor angkatan VI). Atau lihat Henri Shalahuddin, Alquran Dihujat (Jakarta: Al-Qalam, 2007), hal. 86

${ }^{29}$ Nașr Hamid Abū Zayd, Mafhum al-Nāṣ Dirasah fì 'Ulūm al-Qur'ān, h. 19.

${ }^{30}$ Nașr Hamid Abū Zayd, Mafhum al-Nāṣ Dirasah fì 'Ulūm al-Qur'ān, h. 20.

${ }^{31}$ Adian Husaini dan Abdurrahman Al-Baghdadi, Hermeneutika \& Tafsir Alquran, h. 20.

${ }^{32}$ Adian Husaini dan Abdurrahman Al-Baghdadi, Hermeneutika \& Tafsir Alquran, h. 19-20.
} 


\section{Pilkada DKI Jakarta: Sebuah Fenomena}

Menelusuri sejarah kemerdekaan Republik Indonesia tahun 1945 Jakarta telah mengalami beberapa kali pergantian pemimpin. Mulai dari Gubernur pertama Suwiryo (1945-1951) ${ }^{33}$ sampai dengan Joko Widodo (2014). Berikut adalah nama nama Gubernur DKI Jakarta dari masa ke masa: Raden Suwiryo (2 Periode) 1945-1947, 1950-1951; Letnan Kolonel H. Daan Jahja (1948-1950); Syamsurijal (1951-1953); Sudiro (1953-1960); Dr. Soemarno Sosroatmodjo, 2 Periode (1960-1964)-(1965-1966); Hendrik Hermanus Joel Ngantung (1964-1965); Ali Sadikin (1966-1977); Tjokropranolo (1977-1982); R. Soeprapto (1982-1987); Letjen TNI (Purn) Wiyogo Atmodarminto (1987-1992); Jendral TNI (HOR) Soerjadi Soedirdja (1992-1997); Letjen TNI (Purn) Dr. (HC) H. Sutiyoso (1997-2002), (2002-2007); Dr. Ing. H Fauzi Bowo (2007-2012); Ir. H. Joko Widodo (2012-2014); dan Ir. Basuki “Ahok" Tjahaja Purnama, M.M (2014/PLT). ${ }^{34}$

Dari nama-nama di atas, yang menyita perhatian penulis adalah sosok Ahok pada Pilgub DKI Jakarta 2017 yang melibatkan isu agama, dapat dilihat bagaimana kelompok-kelompok Islam dapat bergerak secara massif dan intensif. Hal yang tidak dapat dipungkiri dalam peristiwa tersebut menggambarkan bagaimana kontestasi pemilu yang bersinggungan dengan isu keagamaan, atau sebaliknya, telah membawa dampak yang signifikan terhadap persepsi keamanan nasional..$^{35}$

Dalam catatan Kontras, sejak periode kampanye Pilkada DKI Jakarta dimulai pada Oktober 2016, Jakarta memiliki babak baru dalam dunia politik maupun sosial. Setidaknya, sampai pengumuman hasil pemungutan suara, ada beberapa kejadian besar, seperti dugaan penistaan agama yang dilakukan oleh Basuki Tjahaya Purnama (Ahok) bermula dari al-Mā'idah 51 yang diucapkannya, disusul Aksi Bela Islam 4 November 2016, sampai pemberitaan Allan Nairn (seorang jurnalis investigasi asal Amerika) tentang kudeta, dan situasi lain yang menimbulkan teror. Isu tersebut muncul di tengah situasi politik yang seolah terbagi menjadi dua kubu antara kelompok konservatif dan kelompok progresif. ${ }^{36}$

Dalam konteks penistaan agama di sini Gubernur Jakarta yang dikenal dengan Ahok terjadi pada 30 September 2016, dalam percakapan dengan warga kepulauan Seribu, Ahok menyatakan tidak masalah jika warga yang "dibohongi peke Surat alMa'idah ayat 51 dan macem-macem" tidak memilihnya dalam pemilihan Gubernur DKI Jakarta. Di sini dalam pidato yang dipaparkan oleh Ahok diterima oleh sebagian pihak adalah penistaan agama. ${ }^{37}$

${ }^{33}$ Darul Syahdanul, Strategi Komuniti dalam Berpolitik(Universitas Indonesia, 2016), h. 16.

${ }^{34}$ Lihat Ringkasan Sejarah Jakarta, h. 4. Atau akses http://bkddki.jakarta.go.id/unduh/bkd/hutdki/485/20120621 RINGKASAN_SEJARAH JAKARTA.pdf

${ }^{35}$ Ari Ganjar Herdiansah dkk., Pembelahan Ideologi, Kontestasi Pemilu, dan Persepsi Ancaman Keamanan Nasional: Spektrum Politik Indonesia Pasca 2014?, h. 69..

36

https://www.kontras.org/data/20170615 Pilkada Persekusi dan Teror_Negara 09i13j549u135.pdf ${ }^{37} \mathrm{https} / /$ www.youtube.com/watch? $\mathrm{v}=\mathrm{MNdJv3ZAqQE}$ 


\section{Perubahan Paradigma Penafsiran Alquran}

Kajian ini menguraikan perubahan penafsiran ayat-ayat Alquran yang ditemukan dalam situs-situs internet yang menghiasi dunia politik termasuk Pilkada DKI Jakarta. Ayat-ayat tersebut penulis tafsirkan dengan berbagai varian, metode, atau pendekatan serta argumen-argumen yang kontekstual. Lebih tepatnya tujuan dari pembahasan ini adalah mencoba memahami dan menafsirkan ayat-ayat tersebut dengan cara yang benar sesuai kaidah-kaidah penafsiran yang berlaku. Pengembangan berikutnya oleh penulis bahas secara kritis untuk menghindari kesalahpahaman dan memicu perdebatan.

\section{Larangan menjadikan Yahudi, Nasrani (Kafir) sebagai “awliya}

Pembahasan QS. al-Mā'idah [5]: 51 sebagai larangan memilih pemimpin non muslim menjadi isu yang paling pelik, di dalamnya banyak perbedaan cara pandang, sebagian juga dibumbui semata-mata faktor kepentingan politik. Perbedaan pendapat para ulama tentang pemimpin non muslim dapat dipetakan ke dalam dua kelompok; pertama, mereka yang menolak pemimpin non muslim. Kedua, mereka yang mendukung pemimpin non muslim. Kelompok pertama ini seperti al-Zamakshari (467538 H.) dalam al-Kashshäf, Ibn al-'Arābī (468-543 H) dalam Aḥkām al-Qur'ān, alQurțubi $(671 \mathrm{H})$ dalam al-Jāmi' li-Aḥkām al-Qur'ān, al-Tsa'ālabì (786-875 H.) dalam Tafsìr al-Tsa'ālabì dan lain sebagainya.

Pada perkembangannya, banyak yang mengutip ulama-ulama tersebut seperti Rizieq Shihab. ${ }^{38}$ Ia menyampaikan dalam Mimbar Rasil dengan tema "Kewajiban Memilih Pemimimpin Muslim.” Dalam ceramahnya, ia menjelaskan bahwa QS. alMā'idah [5]: 51 sangat singkat, padat, ringkas, jelas dan tidak perlu repot-repot lagi untuk menafsirkannya. Secara tekstual, ayat ini sudah disepakati para ulama sebagai salah satu dalil larangan (haram) umat muslim memilih pemimpin non-muslim (kafir). Ayat ini sebagai cara komunikasi Allah "bi al-nidā' al-ḥabïb”, artinya seruan dengan penuh kasih sayang dalam kalimat “yā ayyuhā al-dhīna āmanü', duhai orang-orang yang beriman. Setelah itu Allah memberi tahu kepada orang-orang yang beriman supaya tidak sekali-kali mengambil Yahudi dan Nasrani sebagai awliyāa, ${ }^{39}$ Kata awliyā' bentuk plural (jamak) dari kata wāî, kata wali ini memiliki arti sangat beragam. Secara bahasa, pengertian dasar kata wali artinya yang dekat, jadi ketika orang disebut waliyullāh berarti orang yang dekat dengan Allah, seperti orang yang beribadah, melaksanakan segala perintah, dan menjauhkan diri dari segala maksiat.

\footnotetext{
${ }^{38}$ Nama lengkapnya Al-Habib Muhammad Rizieq bin Husein Syihab, kelahiran Jakarta, 24 Agustus 1965, merupakan generasi ke-38 dari Rasulullah saw. Ia menyelesaikan pendidikan S1 Bidang Fikih dan Ushul Fikih di King Saud University-Riyadh, Saudi Arabia. Dan meraih S2 Bidang Syriah di Universiti Malaya-Kuala Lumpur, Malaysia. Lihat Buku karya Habib M. Rizieq bin Husain Shihab, Dialog FPI Amar Ma'ruf Nahi Munkar: Menjawab berbagai Tuduhan terhadap Gerakan Nasional Anti Ma'siat di Indonesia (Jakarta: Pustaka Ibnu Sidah, 2004)

${ }^{39}$ Mimbar Rasil, "Habib M Rizieq Syihab - QS AlMaidah Ayat 51-52 Part 1" diakses dari https://www.youtube.com/watch?v=vdQSBjluIdc
} 
Selain itu, wali juga punya arti selain yang dekat; teman setia, pelindung, penolong, pemimpin, bahkan kadang-kadang diartikan sebagai pengurus yang mengatur urusan.

Selain itu, pendapat Rizieq juga didukung Said Agil Husin saat menjawab pertanyaan salah satu peserta dalam Seminar Nasional "Alquran untuk Semua" di UIN Jakarta. Menurutnya, tidak ada lagi yang perlu ditafsirkan dari al-Mā'dah ayat 51. Menurutnya, ayat itu sudah jelas untuk tidak menjadikan non muslim sebagai pemimpin. Alquran menegaskan dua kali dengan kata lā, tidak ada ta'wil yang lain, lā nahyi yufíd al-tahrim, yang berarti tidak boleh atau jangan sekali-kali, bukan hanya muwalah (urusan kepemimpinan), termasuk yanșurūnahum (mendukung), wa yastanșarūnahum (meminta dukungan), wa yuṣāffuna bihim, wa mu'asharatuhum. Pendapat Said Aqil Husin nyatakan dengan mengutip al-Ṣābūnì dalam al-Ṣafwat alTafāsir dan kitab-kitab tafsir lainnya. ${ }^{40}$

Rizieq mengkritik pembatasan makna yang dilakukan oleh orang tertentu (kelompok kedua) meletakan pada mafhum mukhālafah (memahami yang tersirat, kebalikan dari yang tersurat). Tersirat ialah membatasi dua makna, yaitu dilarang Yahudi dan Nasrani sebagai pelindung atau teman setia, dengan artian bahwa dibolehkan mengangkat sebagai pemimpin. Untuk menanggapi upaya tertentu, Rizieq mensiasati dengan menghilangkan mafhum muwäfaqah (memahami yang tersirat, sejalan dengan yang tersurat), dapat dikatakan yang tersirat lebih utama daripada yang tersurat; artinya, kalau dijadikan sebagai pelindung atau teman saja tidak boleh apalagi sebagai pemimpin. Karena setiap pemimpin wajib menjadi pelindung yang dipimpin, atau pemimpin suatu kota wajib menjadi pelindung warga di kotanya. Penekanan di sini dengan menggunakan mafhum muwāfaqah bahwa ayat al-Mā'idah ayat 51 berlaku untuk kepemimpinan. Artinya, orang-orang Yahudi dan Nasrani tidak boleh diangkat menjadi pemimpin bagi umat Islam. ${ }^{41}$ Penafsiran QS. al-Mā'idah [5]: 51 dianggap tidak ada perbedaan pendapat di antara ulama salaf dan khalaf. Seperti di negara Islam (mayoritas muslim), yang ia maksud adalah Indonesia tidak diperbolehkan dipimpin orang kafir. Berbeda, apabila seorang muslim yang tinggal di negara kafir, maka diperbolehkan memilih pemimpin kafir sebagaimana kaidah fikih “ الضَّرُوْرَات تُنْيُحُ "الَحَخْظُوْرَات dimana keadaan darurat membolehkan suatu yang terlarang.42

Penjelasan Rizieq di atas jelas telah keluar dari konteks. Artinya, sebagaimana pendapat Sahiron Syamsuddin yang mengutip teori Abdullah Saeed, bahwa apa yang diuraikan Rizieq lebih subyektif yang mencoba menafsirkan ayat Alquran dengan mengabaikan makna historis/aslinya. Upaya yang dilakukan Rizieq nampak hanya berfokus pada pentingnya teks Alquran untuk kebutuhan kontemporer semata. ${ }^{43}$ Atau

${ }^{40}$ http://www.uinjkt.ac.id/id/ini-kata-said-aqil-husin-al-munawar-tentang-tafsir-al-maidah-51/

${ }_{41}$ Mimbar Rasil, "Habib M Rizieq Syihab - QS AlMaidah Ayat 51-52 Part 1" diakses dari https://www.youtube.com/watch?v=vdQSBjluIdc

${ }^{42}$ Mimbar Rasil, "Habib M Rizieq Syihab - QS AlMaidah Ayat 51-52 Part 2 diakses dari https://www.youtube.com/watch?v=scGZRpBpS_U

${ }^{43}$ Sahiron Syamsuddin, "Ma'na-cum-maghza Approach to the Qur'an: Interpretaton of Q. 5: 51", Call For Papers International Conference on Quran and Hadith Studies and the 2nd Annual Meeting of Indonesian Association of Qur'anic Studies (AIAT), Jakarta; 6-8 November 2017, h. 1. 
dapat dikatakan bahwa Rizieq kurang memahami ayatnya, tidak memperhatikan konteks historisnya, aspek linguistiknya, dan gagasan moralnya. Lebih jelasnya, apa yang penulis asumsikan terhadap Rizieq ini dijelaskan Sahiron, ketika menjelaskan QS. al-Mā'idah [5]:51 ini berisi tentang larangan umat Islam mengangkat kaum Yahudi dan Nasrani sebagai awliyā'. Sahiron menguraikan arti kata tersebut, konteks historisnya, dan ide moral yang mungkin dikandung oleh ayat tersebut.

Pertama, terkait dengan aspek bahasa, sebenarnya ayat tersebut mengandung beberapa kosa kata yang harus dianalisis secara cermat. Kata awliyā', Hamka dalam Tafsir al-Azhar menerjemahkan sebagai 'pemimpin-pemimpin'. ${ }^{44}$ Berbeda ketika merujuk kitab tafsir klasik, Muhammad Ibn Jarir al-T abari, misalnya, menafsirkan kata awliyā' dengan anșar wa hulafá, (penolong-penolong dan aliansi-aliansi atau temanteman dekat). ${ }^{45}$ Terjemahan yang mendekati dengan penjelasan al-Tabari adalah terjemahan Quraish atas kata tersebut: 'para wali' (teman dekat dan penolong). ${ }^{46}$ Singkat kata, baik al-Tabari maupun Quraish tidak menafsirkan kata tersebut dengan pemimpin-pemimpin pemerintahan.

Kedua, dari segi konteks historis, para ulama berbeda pendapat terkait sabab nuzul, mereka menyebutkan beberapa riwayat yang bervariasi. Sebagian mengatakan bahwa ayat tersebut berkenaan dengan kisah 'Ubadah ibn al-Shamit yang tidak lagi mempercayai kaum Yahudi dan Nasrani di Madinah sebagai aliansi yang bisa membantu umat Islam dalam peperangan, dan 'Abdullāh Ibn Ubayy Ibn Salul yang masih mempercayai mereka sebagai kawan dalam peperangan. Sebagian riwayat lain menerangkan bahwa ayat tersebut berkaitan dengan Abū Lubabah yang diutus Rasulullah saw. kepada Banu Quraizhah yang merusak perjanjian dukungan dan perdamaian dengan Rasulullah dan umatnya. Riwayat yang lain lagi merangkan bahwa ayat tersebut terkait dengan kekhawatiran umat Islam menjelang terjadinya perang Uhud (pada tahun kedua Hijriyah); karena itu, sebagian dari mereka mencoba meminta bantuan teman-teman Yahudi, dan sebagian yang lain ingin meminta bantuan kepada kaum Nasrani di Madinah; ayat tersebut turun untuk menasehati umat Islam saat itu agar tidak meminta bantuan kepada mereka. Terlepas dari variasi riwayat-riwayat tersebut di atas, bisa digarisbawahi bahwa ayat tersebut turun dalam konteks peperangan, dimana kehati-hatian dalam strategi perang harus selalu diperhatikan, sehingga tidak boleh meminta bantuan dari pihak-pihak lain yang belum jelas komitmennya. Konteks historis turunnya ayat itu bukan pertemanan dalam situasi damai, dan bukan pula konteks pemilihan kepala pemerintahan.

Ketiga, ide moral atau pesan utama dari ayat itu sebagai berikut; 1) Perintah untuk berteman dengan orang-orang yang bisa dipercaya, khususnya dalam hal-hal yang sangat penting dalam kehidupan bermasyarakat, dan larangan untuk memilih teman yang suka berkhiyanat. Prilaku adil kepada semua orang harus ditegakkan dan

\footnotetext{
${ }^{44}$ Hamka, Tafsir Al-Azhar, juz 6, h. 273.

${ }^{45}$ Al-Ṭabarī, Jami` al-Bayan, juz 8, h. 507.

${ }^{46}$ Q. Shihab Shihab, Alquran dan Maknanya (Jakarta: Lentera Hati, 2010) h. 117. Atau lihat juga M. Quraish Shihab, Tafsir Al-Misbah, vol. 3, h. 150-151.
} 
ketidakadilan harus ditinggalkan. 2) Perjanjian bersama tidak boleh dikhiyanati. Apabila komitmen/perjanjian itu dirusak secara sepihak, maka yang akan terjadi adalah kehilangan trust (kepercayaan) dari kelompok yang dikhiyanati, sebagaimana kehilangan trust umat Islam Madinah pada masa Nabi kepada kaum Yahudi dan Nasrani yang menyalahi The Medinan Charter (Piagam Madinah) yang salah satu intinya adalah saling menolong dan membantu antar-komunitas saat itu di Madinah. 3) Ayat tersebut tidak ada hubungannya dengan pemilihan kepala negara/ daerah. Islam hanya mengajarkan bahwa kepala negara atau daerah sebaiknya orang yang mampu berbuat adil kepada seluruh masyarakat yang berada di wilayah kekuasaannya, tanpa sentimen SARA. ${ }^{47}$

\section{Kewajiban berbuat adil}

Penjelasan Rizieq di atas sangat tegas menolak kepemimpinan non muslim, Said Agil Siradj justru lebih mengutamakan pemimpin yang adil non muslim jauh lebih baik daripada pemimpin muslim yang zalim, ia menjelaskan dengan mengutip statement dari Taqìy al-Dīn Abū al-'Abbās Ibn 'Abd al-Ḥalim Ibn 'Abd al-Salām Ibn Taimiyyah dalam al-Siyāsah al-Syar'iyyah fî Ișlāḥ al-Rā'iy wa al-Ra'iyyah, yang dinyatakan bahwa persoalan-persoalan kemanusian itu bisa tegak di dunia ini hanya dengan keadilan, yang boleh jadi pemerintah yang menegakkan keadilan itu (melakukan dosa) sendiri adalah non muslim, itu lebih tegak daripada orang yang dalam hal agama (tidak melakukan dosa) tapi zalim. Sesungguhnya Allah akan memperkuat negara yang adil walau negara itu dipimpin oleh seorang non muslim (kafir), dan Allah tidak akan memperkuat negara yang zalim walau negara itu dipimpin seorang muslim. Dunia ini bisa tegak dengan keadilan dan kekufuran, dan tidak akan bisa tegak dengan kezaliman dan Islam." Ditegaskan kembali, bahwa lebih penting di sini adalah keadilannya, karena pemimpin muslim atau non muslim tidak masuk dalam konteks suatu negara. Nabi Muhammad saw bersabda: Tidak ada dosa yang oleh Allah cepat disiksa di dunia ini, yaitu; kezaliman dan memutus silaturrahim." Maka orang yang zalim akan dihancurkan di dunia oleh Allah, walaupun orang itu nanti di akhirat diampuni masuk surga karena ia orang Islam, tapi ia jadi pemimpin yang zalim akan mendapatkan ancaman (sanksi) dari Allah di dunia ini. Kenapa demikian? karena keadilan itu adalah at uran (sistem) segala sesuatu, maka apabila dunia ini diatur dengan keadilan, dunia akan tegak, walaupun pemimpinnya itu bukan seorang muslim, di akhirat tidak akan mendapatkan pahala. Ketika dunia ini tidak diatur dengan keadilan, maka dunia akan hancur, walaupun pemimpinnya ini seorang muslim, di akhirat akan mendapatkan pahala dari imannya saja, tetapi ketika di dunia ia memimpin pemerintahan dengan zalim walaupun muslim akan hancur, tapi pemimpin non muslim yang adil akan dapat

47 Sahiron Syamsuddin, Ma'na-cum-maghza Approach to the Qur'an, h. 3. Atau http://uinsuka.ac.id/v2016/kolom/detail/52/penafsiran-kontekstualis-atas-qs-al-maidah-51 atau lihat http://aiat.or.id/2017/10/28/penafsiran-kontekstualis-atas-q-s-al-maidah-51/ 
memperkuat atau melanggengkan pemerintahannya, walaupun di akhirat tidak akan mendapatkan pahala karena tidak beriman. ${ }^{48}$

Dalam konteks hiruk pikuk politik saat ini, atas Ahok (non muslim) mencalonkan diri sebagai Gubernur DKI Jakarta ini sangat relevan atas pertarungan tiga pasangan calon kandidat dari kalangan muslim dan non muslim. Di samping itu, Said Agil yang terkenal pemikiran progresifnya bukan maksud untuk mendukung secara pasti terhadap kepemimpinan non muslim, hanya saja penulis menyimpulkan bahwa apa yang disampaikan Said Agil tidak lain untuk memberikan pemahaman luas kepada umat Islam di Indonesia, selian itu, untuk meredam kontreversi seputar boleh tidaknya non muslim menjadi pemimpin bagi umat Islam. Maka, dapat dikatakan Ibn Taimiyah dan Said Agil Siradj masuk dalam kelompok kedua yang mendukung kepemimpinan non muslim.

Penjelasan Said Agil Siradj juga diperkuat QS. Āli 'Imrān [3]: 28 “Janganlah orang-orang mukmin mengambil orang-orang kafir menjadi wali ..." Konteks ayat ini ketika ada pemimpin muslim yang memenuhi syarat. Jika ada dua calon; muslim dan non muslim sama-sama memenuhi syarat; kapasitas, kapabilitas, berakhlak, moral, integritas yang baik, sama-sama mampu adil dan bersih, maka mendahulukan yang muslim. Tapi kalau yang seorang muslim tidak memenuhi syarat tersebut, jangan dipilih menjadi seorang pemimpin. Dan apabila seorang non muslim itu memenuhi syarat tersebut, maka lebih baik memilih 'yang adil' walau itu seorang non muslim. Karena keadilan dari seorang pemimpin adalah sistem (aturan) di dunia, jadi tidak dapat dikaitkan dengan masalah agama. Ketika di negara mayoritas muslim (Indonesia) tidak dapat menghadirkan atau melahirkan pemimpin yang tidak memenuhi syarat, maka akan menjadi dosa bersama. Said Agil juga mencontohkan negara-negara yang hancur karena dipimpin seorang muslim yang (dhalim) tidak adil, seperti Sadam Husain (Irak) membunuh banyak ulama, Hafez al-Assad (Suriah) pembantaian dengan membumihanguskan kota Hama yang mayoritas Ahl al-Sunnah, Jamal Nasser (Mesir) mengeksekusi mati ulama, seperti Sayyid Quthb ${ }^{49}$ seorang pengarang tafsir Fì Zilāl al-Qur'ān dan Muḥammad Asymāwī Zakì (muhaddith) digantung, tidak jauh seperti zaman Orde Baru sebagai pembantaian para jenderal pada peristiwa G30S/PKI.

Dari contoh pembantaian ulama-ulama di atas, bukan berarti tidak ada sebab, penulis menyinggung bahwa kehancuran Islam ada kemungkinkan kelompok tertentu salah dalam memahami Islam itu sendiri atau mencita-citakan berdirinya negara Islam, yang diwakili oleh Wahhabi, Ikhwan al-Muslimin dan Hizbut Tahrir, ${ }^{50}$ sampai negara Indonesia menjadi salah satu tujuannya. Sintesis ini tergambar juga pada organisasi masyarakat di Indonesia, seperti FPI yang mulanya dengan tujuan mulia "amar ma'ruf

48 Anin, “ini Dia Pendapat Aa' Gym dan KH Said Aqil Siradj Terkait Pemimpin Non Muslim”, diakses dari https://www.youtube.com/watch?v=mc6JrWF_pB0

49 Lihat Aksin Wijaya, Satu Islam Ragam Epistemologi: Dari Epistemologi Teosentrisme ke Antroposentrisme (Yogyakarta: Pustaka Pelajar, 2014), h. 346.

${ }^{50}$ Aksin Wijaya, Satu Islam Ragam Epistemologi, h. 345. 
nahi munkar" sekarang bermuara pada jargon "Bela Islam" dan "Penegakan Syariat", akhirnya konsep dakwahnya yang ditempu mengutamakan politik katimbang urusan agama. ${ }^{51}$ Kelompok ini dinilai lebih menggeluti Islam dengan dua wajah; Islam dan kekuasaan, Islam dan Politik, Islam dan negara.

Pemikiran Islam dengan dua wajah diuraikan Aksin Wijaya nampak menyudutkan kelompok tertentu. Sebelumnya, Said Agil Siradj lebih mengutamakan keadilan dalam urusan kekuasaan baik pemimpinnya seorang muslim atau non muslim. Hal ini, juga pernah disampaikan Abdurrahman Wahid (Gus Dur) saat itu berkampanye untuk memberi dukungan Ahok atas pencalonan Gubernur di Bangka Belitung tahun 2007. Gus Dur menilai pencalonan Ahok sebagai pemimpin layak karena dalam urusan kepemimpinan, Ahok mempunyai syarat yang jujur dan pandai dalam urusan pemerintahan. Maka memilih pemimpin non muslim yang jujur dalam hal ini "tidak apa-apa". Pembuktiannya itu bahwa Ahok mampu membuktikan sebagai pemimpin saat melaksanakan tugas sebagai Bupati Belitung Timur periode 2005-2006 dengan program terbaiknya untuk membebaskan biaya kesehatan kepada seluruh warganya. ${ }^{52}$

\section{Kewajiban mentaati Pemimpin (Pemegang Kuasa)}

Perlu diuraikan kembali, bahwa pelarangan non muslim menjadi pemimpin mencuat sejak Ahok mencalonkan diri sebagai Gubernur di Bangka Belitung 2007, namun akhirnya kalah dan maju menjadi Wakil Gubernur DKI Jakarta berpasangan dengan Jokowi pada tahun 2012. Pada saat bersamaan muncul penolakan keras oleh kelompok atas kepimpinan non muslim. Penulis mengulas tulisan M. Suryadinata bahwa kelompok penentang terhadap kepemimpinan non muslim adalah FPI. Pemimpin tidak sesuai dengan ajaran Islam maka tidak perlu diikuti dan dihiraukan. ${ }^{53}$ Pernyataan keras ini jelas sebagai bentuk himbauan kepada umat Islam yang sudah terlanjur dipimpin oleh Ahok. Kontestasi tersebut berimbuh pada sikap kelompok yang dipimpin Rizieq Shihab terkait anjuran mentaati pemimpin.

Secara garis besar, penjelasan QS. al-Nisā' [4]: 59 mencakup tiga kategori; taat kepada Allah, Rasul dan $\bar{u} l i$ al-amr. Penekanan ayat ini lebih dominan pada penafsiran kata $\bar{u} \bar{i}$ al-amr. Kelompok ini menafsirkan QS. al-Nisā' [4]: 59 sebagai dasar mentaati pemimpin. Hanya saja, mereka menafsirkan kata " taatilah adalah untuk Allah, kemudian untuk Rasulullah saw, sedangkan untuk kategori ketiga, $\bar{u} \bar{i}$ al-amr ditafsirkan secara berbeda. Mereka membatasi makna $\bar{u} / \bar{i}$ al-amr, pasalnya $\bar{u} \bar{i}$ al-amr ditafsirkan mencakup makna "ulama" dan "umara”. Kata tersebut hanya di- 'ataf-kan (digabungkan) pada kata sebelumnya. Pemaknaan tersebut sebagai isyarat Ilahiah, bahwa taat kepada Allah dan Rasulullah adalah bersifat mutlak, sedangkan untuk $\bar{u} \bar{i}$

51 Yusuf Hanafi, "Pemikiran Politik dalam Tafsir Fath Al-Qadir: Pembacaana atas Konsep Ketatanegaraan dalam Alquran yang ditulis Al-Syaukānı̄”, Hemeneutik, Vol. 9, No. 2, Desember 2015, h. 382-383.

${ }^{52} \mathrm{http}$ ://jakutnews.com/profil-calon-gubernur-incumbent-dki-jakarta-basuki-tjahaja-purnama/

${ }_{53}$ M. Suryadinata, "Non Muslim dalam Alquran: Analisis terhadap Penafsiran FPI Mengenai Ayat Pemimpin Non Muslim”, Ilmu Ushuluddin, Volume 2, Nomor 2, Januari-Juni 2015, h. 248. 
al-amr bersifat relatif, tergantung jika sesuai dengan kehendak Allah dan Rasulullah. Bila sesuai syari'at wajib ditaati, bila tidak, haram untuk ditaati. ${ }^{54}$ Berbeda hukum negara yang dibuat manusia, sifatnya tidak mutlak. Penegasan mereka, apabila hukum negara itu sesuai dengan norma-norma agama maka wajib ditaati, sebaliknya jika berbenturan dengan ajaran agama harus ditolak. Penolakan ini dibutuhkan strategi dan siasat. ${ }^{55}$

Apabila pengertian $\bar{u} \bar{i}$ al-amr dibatasi dengan makna ulama dan umara, penulis anggap itu keliru. Ketika ditelusuri sesuai kaidah linguistik, "ulama merupakan bentuk plural dari 'ālim, berasal dari kata kerja 'alima, yang berarti "mengetahui" atau "berpengetahuan tentang agama". ${ }^{56}$ Dari pengertian ulama ini mengalami penciutan makna dan tidak bermakna jamak lagi, tapi tunggal; yaitu, orang yang hanya mengetahui dan memahami ilmu agama secara mendalam. ${ }^{57}$ Sedangkan umara berasal dari kata amara, yang bermakna menyuruh, ${ }^{58}$ yang memiliki otoritas serta kebijakan dalam mengendalikan suatu sistem pemerintahan. Dari upaya mereka membatasi pengertian tersebut, dengan menyandingkan kata ulama dan umara ini dapat diasumsikan bahwa sebuah sistem tatanegara harus sesuai syari'at Islam. Ini menandakan, bahwa terlepas sistem pemerintahannya seperti apa, yang terpenting dipimpin oleh seorang muslim, bukan non muslim. Maka, menurut mereka, tidak ada kewajiban mentaati pemimpin dari non muslim. Penjelasan tersebut berbeda dari Quraish. Quraish memaknai $\bar{u} \bar{i}$ al-amr adalah orang-orang yang berwewenang mengurus urusan kaum muslim, orang-orang dapat diandalkan dalam menangani persoalan-persoalan kemasyarakatan, atau yang disebut para penguasa/pemerintah. ${ }^{59}$ Menurut Quraish, al-amr berbentuk ma'rifah atau difinite (pasti), yang harus dibatasi sebagai wewenang pemilik kekuasaan itu hanya persoalan-persoalan kemasyarakatan, bukan persoalan akidah atau keagamaan murni. ${ }^{60}$ Artinya, penjelasan tersebut menguatkan kembali bahwa tidak ada batasan menyangkut persoalan pemilik kuasa itu seorang muslim atau non muslim, yang harus tetap ditaati.

Penjelasan Rizieq di atas, ketika mengikuti teori Abdullah Saeed, jelas pola penafsiran Rizieq menempuh tradisi berbasis textualist/textualisme. Artinya, mereka sangat ketat sekali dalam upaya menafsirkan teks ayat, tanpa mempertimbangkan sisi makna lain, dan mengabaikan konteks sosio-historis Alquran. Dengan kata lain, tradisi semacam itu kecenderungannya didominasi oleh linguistik tafsir klasik sebagai tafsir

${ }^{54}$ M. Suryadinata, Non Muslim dalam Alquran, h. 249. Atau lihat Habib M. Rizieq bin Husain Shihab, Dialog FPI Amar Ma'ruf Nahi Munkar: Menjawab Berbagai Tuduhan terhadap Gerakan Nasional Anti Ma’siat di Indonesia (Jakarta: Pustaka Ibnu Sidah, 2008), h. 234-235.

${ }^{55}$ Habib M. Rizieq bin Husain Shihab, Dialog FPI Amar Ma’ruf Nahi Munkar, h. 234.

${ }^{56}$ Wasito Raharjo, "Ulama dan Pesantren dalam Dinamika Politik dan Kultur Nahdlatul Ulama", Article September 2013, h. 4.

${ }^{57}$ Mutohharun Jinan, "Relasi Ulama dan Umara dalam Sejarah Islam", Dirasah Islamiyah, Suara Muhammadiyah 04/96, 16-28 Februari 2011, h. 25.

${ }^{58}$ Mahmud Yunus, Kamus Arab-Indonesia (Jakarta: PT. Hidakarya Agung, tth), h. 48.

${ }^{59}$ M. Quraish Shihab, Tafsir Al-Misbah, vol. 2, h. 460-461.

${ }^{60}$ M. Quraish Shihab, Tafsir Al-Misbah, vol. 2, h. 461. 
yang otoritatif. ${ }^{61}$ Tidak dapat dipungkiri ketika Rizieq meyakini al-Mā'idah 51 salah satu ayat tentang larangan umat Islam mengangkat orang kafir sebagai pemimpin, menurutnya tidak ada perbedaan antara ulama salaf dan khalaf.

Penafsiran tekstualis Rizieq di atas sangat wajar, akan tetapi yang perlu digarisbawahi di sini bahwa penjelasan yang diterima oleh masyarakat awam dimungkinkan menjadi polarisasi baru, atau menciptakan budaya kebencian terhadap non muslim, sebab kebenaran yang diberikan adalah makna lahiriah Alquran, bagi mereka yang tidak bisa berpikir dengan menggunakan metode demonstratif, lantaran "kebiasaan" dan "sebab pembelajaran", sementara secara alamiah mereka mempunyai akal yang cerdas. ${ }^{62}$

\section{Yahudi, Nasrani selalu mengajak orang lain keagamanya}

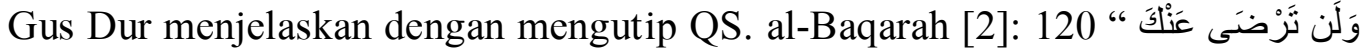

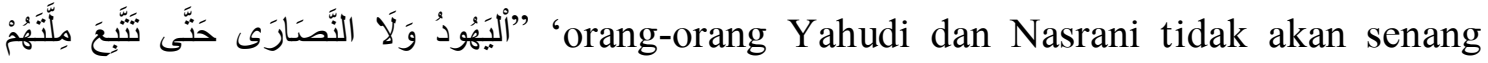
kepada kamu (Muhammad) hingga kamu mengikuti agama mereka.' Ayat ini dianggap sebagai cara untuk menakut-nakuti warga Belitung, dengan dalih ketika memilih pemimpin non muslim sama saja mengikuti agama Ahok. Ditegaskan Gus Dur bahwa ayat tersebut tidak ada kaitannya dengan urusan kekuasaan, pencalonan Ahok sebagai Gubernur, atau mengkaitkan urusan agama dengan politik. Jadi memilih Ahok, bukan berarti mengikuti agamanya. ${ }^{63}$ Mencuat pernyataan Gus Dur untuk mendukung Ahok yang sebelumnya isu agama dan suku sudah digunakan oleh para lawan politiknya untuk menjatuhkan Ahok. Terlebih dikabarkan bahwa banyak selebaran di jalan-jalan dan di masjid-masjid berisikan ayat-ayat Alquran (al-Mā'idah [5]: 51, al-Nisā' dan alḤujurāt [49]: 13) yang menegaskan agar tidak memilih pemimpin non muslim. ${ }^{64}$

Pemahaman yang diberikan Said Agil Siradj di atas, dan dikuatkan Gus Dur ketika menafsirkan ayat tentang pemimpin non muslim (Ahok) ini membuka jalan tengah yang memahami Islam tidak dalam kerangka relasinya dengan kekuasaan, politik dan negara, melainkan dalam konteks nalar ajarannya. Yang dimaksud nalar ajaran dalam hal ini adalah Islam dilihat dari segi argumennya. Sebab, ada perbedaan subtansial antara cara memahami Islam secara konseptual dengan memahami Islam secara semantik dan definitif dengan menganalisa kosakata, kalimat, ayat dan surat pada Alquran. Ini berarti baik Gus Dur ataupun Said Agil Siradj, keduanya memahami Islam secara agumentatif di mana Alquran diletakkan sebagai satu kesatuan yang utuh. Yang dimaksud nalar ajaran Islam dalam hal ini adalah Islam bersifat nalar (rasional) ${ }^{65}$

${ }^{61}$ Abdullah Saeed, Interpreting the Qur'an: Towards a Contemporary Approach (London and New York: Routledge, 2006), h. 50.

62 Pola ini mengikuti pandangan Ibn Rushd dalam Aksin Wijaya, Teori Interpretasi Alquran Ibnu Rusyd: Kritik Ideologis-Hermeneutika (Yogyakarta: LkiS, 2009), h. 305.

${ }^{63} \mathrm{https}$ ://www.youtube.com/watch?v=ylbNv6si9T4

64 https://pilkada.liputan6.com/read/2887212/kisah-ahok-diserang-isu-sara-sejak-pilkada-bangkabelitung

${ }^{65}$ Aksin Wijaya, Satu Islam Ragam Epistemologi, h. 347. 


\section{Sentimen SARA (Suku, Agama, Ras, dan Antargolongan)}

Sentimen SARA adalah problem yang biasa dihadapi oleh komunitas tertentu baik inter kelompok maupun antara kelompok-kelompok yang berbeda. Sentimen ini biasanya bersumber dari klaim kebenaran yang dikedepankan oleh para pimpinan masing-masing kelompok yang disampaikan dihadapan para penganut atau pengikut organisasi tersebut. ${ }^{66}$

Wujud dorongan kepentingan politik yang memanas saat pencalonan Ahok sebagai Gubernur DKI Jakarta, sebagaimana yang dilakukan mantan preman, Anton Medan membela Ahok karena etnis. Anton Medan adalah seorang Muallaf yang juga sebagai Ketua Persatuan Islam Tionghoa Indonesia (PITI). Ia pernah mengatakan bahwa sifat Ahok lebih islami ketimbang pejabat Muslim yang korupsi. Dari pernyataannya itu, ia dikecam Munarman, seorang tokoh FPI bahwa apa yang dilakukan oleh Anton Medan adalah perbuatan yang menyimpang dari akidah Islam, artinya ia kembali ke jaman jahiliyah. ${ }^{67}$

Sejalan dengan penjelasan Quraish pada sub bahasan di atas, penjelasan secara kontekstual dijelaskan pula Syu'ba Asa ketika menafsirkan QS. al-Hujurāt [49]: 13. Syu'ba Asa membaca sebuah peristiwa yang dilakukan sesama bangsa sendiri yang menatasnamakan "warga keturunan" atau "pribumi." Hal ini baru-baru juga dilayangkan Anies Baswedan soal "Pribumi" dalam pidato politiknya setelah dilantik sebagai Gubernur DKI Jakarta pada 16 Oktober 2017 dinilai kurang tepat. Sebelumnya, Anies mengatakan bahwa "Jakarta merupakan satu dari beberapa tempat yang merasakan hadirnya penjajahan, selama berabad-abad lamanya rakyat pribumi ditindas dan dikalahkan kolonialisme, dan saatnya pribumi menjadi tuan rumah di negeri sendiri." Pidato ini dinilai mendatangkan polarisasi baru, yang membedabedakan atas dasar apapun, baik itu agama, ras, warna kulit ataupun golongan. ${ }^{68}$ Ucapan Anies tidak lain menyudutkan etnis Cina, lebih diarahkan pada sosok Ahok. Peristiwa yang dijelaskan Syu'ba Asa di sini mengungkap sejarah yang mencatat kasus pembantaian terhadap etnis Cina itu saat peristiwa Mei 1998 di Jakarta dan Solo. ${ }^{69}$

Penjelasan kata dasar "pribumi" atau "kebangsaan" sedikit aneh kadang juga dipandang secara eksklusif sebagian orang. Karena para pakar berbeda pendapat tentang unsur-unsur yang dipenuhi untuk menamai suatu kelompok manusia sebagai bangsa. Sebelum menjelaskan lebih jauh, penulis merujuk QS. al-Ḥujurāt [49]: 13 sebagai upaya cocokologi (memadukan) atas penjelasan Quraish. Kata (شعوب) shu'ūb jamak dari (شبب) sya’b. Kata ini digunakan menunjuk sebuah kumpulan (قيلة) qabīlah/suku, baik kumpulan sebuah keluarga (عمارة) 'imārah, sampai keluarga yang

${ }^{66}$ Irfan Abu Bakar dan Chaider S. Bamualim, Modul, Resolusi Konflik Agama \& Etnis di Indonesia (Jakarta: Pusat Bahasa dan Budaya [PBB] UIN Syarif Hidayatullah Jakarta, 2006), h. 70.

67 http://www.panjimas.com/news/2014/12/03/mantan-preman-anton-medan-bela-ahok-karenaetnis-munarman-dia-kembali-ke-zaman-jahiliyah/

http://m.tribunnews.com/nasional/2017/10/17/ucapan-anies-soal-pribumi-dapat-membentuk$\frac{\text { polarisasi-di-masyarakat?page }=3}{69}$

http://m.republika.co.id/berita/salarung/nostalgia-abah-alwi/16/09/24/odyxif282-tragedipembantaian-10-ribu-etnis-cina-di-jakarta 
terkecil. ${ }^{70}$ Secara gamblang ia sendiri merasa tidak yakin wawasan Alquran tentang paham kebangsaan. Apakah kata sha'b, qaum, atau ummah menunjukkan konsep bangsa atau kebangsaan? Kata qaum dan qaumiyah sering dipahami dengan arti bangsa dan kebangsaan. Seperti kebangsaan Arab dinyatakan dengan istilah al-Qaumiyah al'Aräbiyyah. Sedangkan kata sha'b dalam terjemahan Alquran Indonesia diartikan sebagai "bangsa." ${ }^{11}$ Syu'ba Asa mengartikan shu'b dipahami untuk non-Arab (qabilah; untuk kelompok Arab), dengan sebutan lain mawla; yang berarti budak dan mantan budak (asing), ${ }^{72}$ atau dapat dikatakan kata mawla sebagai sesuatu yang rendah/kecil.

Quraish melacak kata qaum dalam Alquran ditemukan sebanyak 322 kali. Artinya, dapatkah dikatakan bahwa pengulangan yang sedimikian banyak merupakan bukti bahwa Alquran mendukung paham kebangsaan? Nabi menyeru masyarakatnya dengan "yā qaumî̀ (wahai kaumku/bangsaku). Walaupun mereka tidak beriman kepada ajarannya. Dengan demikian, penggunaan kata ini dapat ditentang sebagian orang ketika dijadikan sebagai paham kebangsaan. Maka Alquran memerintahkan Nabi saw. untuk menyeru masyarakat tidak dengan kata qaumī, tetapi "yā ayyuhā al-nās (wahai seluruh manusia). ${ }^{73}$ Maka dengan demikian, penjelasan yang sepadan dengan paham kebangsaan disamakan dengan asal keturunan, ras, emosi dan lain sebagainya. Paham kebangsaan yang demikian itu sebagai sesuatu yang abstrak, tidak dapat disentuh. ${ }^{74}$

Dari uraian Quraish tersebut, penulis menjabarkan bahwa konsep paham "pribumi" ${ }^{75}$ istilah ini dipahami sebagai kekayaan alam dari masyarakat asli yang telah dirampas asing, sumberdaya mereka dicuri, tokoh-tokoh masyarakat dipenjara dan dibunuh. Maka penulis mengartikulasikan kata "pribumi" secara semantik lebih cenderung sepintas kembali kepada sejarah yang menggambarkan masyarakat yang paling menderita ketika penjajahan Belanda. Ketika menyebutkan bangsa "pribumi", seolah-olah hak pribumi telah digrogoti oleh elit, dan ketika seorang pejabat korup, maka yang terlintas adalah hak rakyat telah dirampas. Untuk menguatkan istilah ini, penulis merujuk tulisan Trisno Mais dalam Memaknai Arti Kata 'Pribumi' yang mengatakan bahwa "pribumi" lebih dimaknai sebagai pemilik suara (rakyat). ${ }^{76}$ Maka dengan demikian, seolah-olah suara rakyat hanya dibutuhkan untuk sebuah kepentingan dalam momentum Pilkada atau Pilpres. Maka, ketika menyebut teks "pribumi" perlu menemukan makna historis, yang menurut Jorge Gracia, merupakan "historical function of interpretation" atau "fungsi penafsiran sejarah", seseorang juga harus memperhatikan situasi historis skala kecil dan besar di mana sebuah ayat atau

${ }^{70}$ M. Quraish Shihab, Tafsir Al-Misbah, h. 261.

71 M. Quraish Shihab, Wawasan Alquran: Tafsir Maudhu'i atas Pelbagai Persoalan Umat (Bandung: Mizan, 2000), h. 331.

${ }^{72}$ Syu'ba Asa, Dalam Cahaya Alquran, h. 8.

${ }^{73}$ M. Quraish Shihab, Wawasan Alquran, h. 332.

${ }^{74}$ M. Quraish Shihab, Wawasan Alquran, h. 334.

${ }^{75}$ Kamus Besar Bahasa Indonesia mengartikan bahwa pribumi adalah penghuni asli. Mereka sudah lama menempati tanah tersebut.

$76 \quad$ https://www.kompasiana.com/zskejflbxi.59e6455f0d2d232d5a125d92/memaknai-arti-katapribumi 
surat pun diungkap..$^{77}$ Jadi konsep paham "pribumi" bagi hermeneutika yang diterapkan Gracia sebagai sesuatu yang sensitif yang perlu perhatian besar karena menyangkut masalah-masalah etnisitas, identitas, nasionalisme dan lain sebagainya, maka perlu dihapus dari lingkup berbangsa dan bernegara.

Syu'ba Asa menilai sebagai cermin sosial, lingkup berbangsa, baik warga keturunan Cina dan apapun itu, harkat manusia yang hak hidupnya harus dibela, bahkan sekalipun ia seorang budak. Syu'ba Asa melarang terhadap tindakan diskriminatif terhadap jenis apapun. ${ }^{78}$ Dapat dilihat bahwa pembacaan Quraish Shihab terkait QS. al-Hujurāt [49]: 13 di atas lebih condong pembelaan terhadap sesama muslim. Berbeda bacaan Syu'ba Asa yang lebih ke arah mengecam dengan memahami ayat ini lebih keseluruhan sesama manusia yang tidak dibeda-bedakan baik dari suku, ras dan agama. Meskipun pada dasarnya penjelasan keduanya sama.

Selain itu, penegasan lain terkait kebebasan beragama diuraikan Syu'ba Asa dengan mengutip QS. al-Baqarah [2]: 148. Ayat tersebut dipahami Syu'ba Asa sebagai ajaran kebebebasan beragama. Sebagaimana di Indonesia, berdasarkan perundangundangan yang diberlakukan memeluk agama Islam, Kristen, Katolik, Hindu, Buddha, dan Konghucu. ${ }^{79}$ Ia menyadari bahwa ayat ini oleh beberapa pendapat ditafsirkan hanya melingkupi umat muslim. Pembacaan Syu'ba Asa, secara eksplisit (sariḥ) dan sisanya implisit (muhtamal) bahwa ayat ini menunjuk pada sasaran yang umum..$^{80}$

\section{Larangan menjadi musyrik}

Pembahasan dalam QS. Luqmān [31]: 13 ini sebuah nasehat yang ditorehkan Luqmān kepada anaknya ${ }^{81}$ tentang syirik sebagai sesuatu aniaya dan kezaliman (dosa) besar. ${ }^{82}$ Di sisi lain ayat ini menggambarkan sebuah kedudukan dalam pemerintahan yang dikisahkan oleh Luqmān. Kezaliman yang dimaksud di sini dijelaskan Hasbi Ash-Shiddieqy. Ia menjelaskan zalim adalah meletakkan sesuatu bukan pada tempatnya. Orang yang menyamakan makhluk dengan Pencipta (Khāliq) atau menyamakan berhala dengan Allah. ${ }^{83}$

Berkenaan dengan siapa Luqmān, ulama sepakat sebagaimana kebanyakan riwayat bahwa Luqmān bukanlah seorang Nabi. Tetapi dia adalah seorang hamba

77 Sahiron Syamsuddin, Hermeneutika dan Pengembangan Ulumul Qur'an (Yogyakarta: Pesantren Nawesea Press, 2009), h. 56.

${ }^{78}$ Syu'ba Asa, Dalam Cahaya Alquran: Tafsir Ayat-ayat Sosial Politik, h. 3 dan 8.

${ }^{79}$ Undang-Undang (UUD) 1945 menyatakan bahwa negara menjamin kebebasan beragama dan kepercayaan (Pasal 28E jo Pasal 29 ayat 1). Bahkan dalam Pasal 281 UUD 1945 dinyatakan bahwa kebebasan beragama tidak dapat dikurangi dalam keadaan appaun. Ketentuan itu masih diperkuat lagi dala Pasal 22 UU Nomor 39 Tahun 1999 tentang HAM. Setiap orang mempunyai kebebabasan berpikir, berkeyakinan, dan beragama. Lihat, Febri Handayani, Konsep Kebebasan Beragama Menurut UUD Tahun 1945 serta Kaitannya dengan HAM, h. 1.

${ }^{80}$ Syu'ba Asa, Dalam Cahaya Alquran, h. 9.

${ }^{81}$ Hamka, Tafsir al-Azhar, juz 21, h. 127-128.

82 M. Hasbi Ash-Shiddieqy, Tafsir Alquran Al-Majid An-Nur (Semarang: Pustaka Rizki Putra, 2000), jilid 4, h. 3207.

${ }^{83}$ M. Hasbi Ash-Shiddieqy, Tafsir Alquran Al-Majid An-Nur, jilid 4, h. 3207. 
Allah yang banyak menampung kebajikan, banyak merenung, dan berkeyakinan lurus. Dalam sebuah kisah, Luqmān pernah tidur di siang hari, tiba-tiba dia mendengar suara memanggilnya seraya berkata: "Hai Luqmān, maukah engkau dijadikan Allah khalifah yang memerintah di bumi?" Luqmān menjawab, "Kalau Tuhanku memberiku pilihan, maka aku memilih afiat (perlindungan) tidak memilih ujian. Tetapi bila itu ketetapanNya, maka akan kuperkenankan dan kupatuhi, karena kau tahu bahwa bila itu ditetapkan Allah bagiku, pastilah Dia (Allah) melindungi dan membantuku. Suara yang memanggil itu (Malaikat) bertanya: "Mengapa demikian?" Luqmān menjawab: "Karena pemerintahan/ penguasa adalah kedudukan yang paling sulit dan paling keruh. Bagi Luqmān, kedudukan di sini diibaratkan sebagai sebuah kezaliman, apabila itu dilakukan dengan mengabaikan kebenaran (tidak berlaku adil), maka ia tidak akan selamat di akhirat. ${ }^{84}$

Dalam kisah Luqmān ini ditegaskan bahwa seseorang apabila dalam menjalani sebuah pemerintahan harus bersikap adil, maka ia selamat di akhirat; dan apabila ia keliru atau zalim, maka ia tidak akan selamat di akhirat. Apa yang dikisahkan Luqmān di sini adalah sebuah nasehat bahwa dalam tatanan sistem pemerintahan hal yang paling penting adalah keadilan. Orang yang berlaku adil berarti ia menjalani amanat sebagai pemimpin di dunia juga tidak mengabaikan urusan di akhirat. ${ }^{85}$

\section{Larangan memberikan jalan (kemenangan) kepada orang kafir}

QS. al-Nisā' [4]: 141 ini disalahgunakan sebagai strategi untuk merebut kekuasaan. Upaya orang tentu adalah menyebarkan isu-isu dan menghimbau kepada seluruh umat Islam untuk tidak memilih pemimpin non muslim. Timbul pertanyaan, kenapa tidak dibolehkan mengangkat Yahudi dan Nasrani sebagai pemimpin? Penjelasan secara tekstual dilayangkan Rizieq dengan jawaban "بَعْضُهُهْ أَوْلَيَاءُ بَغْضِ" sebagian mereka itu adalah pemimpin atau pelindung untuk sebagian yang lain. Artinya, apabila mengangkat Yahudi dan Nasrani sebagai pemimpin umat Islam, maka mereka akan menyalahgunakan kekuasaan dan wewenangnya demi untuk kepentingan golongannya. Maka tidak diperbolehkan memilih Ahok (non-muslim) dan memberikan keluasan memilih pasangan calon dari muslim (Anies Baswedan-Sandiaga Uno dan Agus Yudhoyono-Syilviana), Rizieq menggambarkan dengan mengutip potongan QS.

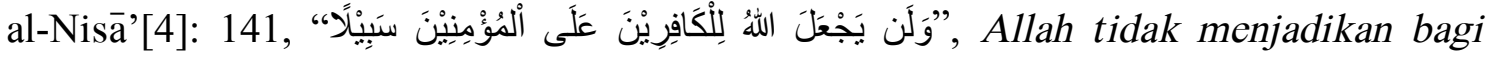
orang-orang kafir satu jalanpun untuk menguasai dan mengerjai orang-orang yang beriman. Ayat ini ditegaskan Rizieq bahwa Allah melarang memberi jalan sekecil apapun kepada orang kafir, ini artinya kalau satu (peluang) jalan saja diberikan kepada mereka maka semua jalan akan mereka kuasai, seperti keputusan bidang ekonomi, politik, keamanan, sosial, dan keagamaan.

Penolakan yang diutarakan Rizieq tersebut untuk mempolitisir sebagai dasar syariat dan penegakkan amar ma'ruf nahi munkar. Selain itu, Muhammad Ismail

\footnotetext{
${ }^{84}$ M. Quraish Shihab, Tafsir al-Misbah, vol. 11, h. 126.

${ }^{85}$ M. Quraish Shihab, Tafsir al-Misbah, vol. 11, h. 126.
} 
Yusanto sebagai juru bicara HTI dalam Aksi Damai bertema "Tolak Pemimpin Kafir, Tolak Ahok" dengan mengutip QS. al-Nisā',4]: 141. ${ }^{86}$ Memahami redaksi ayat tersebut tersirat mengandung celaan dan himbauan, yakni larangan untuk memberikan jalan kepada orang kafir untuk (memimpin) menguasai kaum muslim. Kesan apa yang disampaikan mereka tidak memahami makna obyektif teks, sebagaimana teori HansGeorg Gadamer, seorang penafsir harus mampu mengatasi subyektifitasnya ketika ia menafsirkan sebuah teks. ${ }^{87}$ Maka yang dimaksud di sini adalah seorang penafsir harus sadar bahwa ia berada pada posisi tertentu. Ketika Rizieq menafsirkan sesuatu dalam kondisi hiruk pikuk politik memanas, nampak kecenderungan politis pada dirinya, tanpa ia sadari, setiap ayat yang ditafsirkan selalu berada dalam kepentingan. Maka dengan demikian, dapat dikatakan apa yang ditafsirkan Rizieq sebagai upaya menghindari makna obyektif teks.

Selain itu, pemahaman mereka dapat dikategorikan sebagai upaya untuk menghindari makna historis/asli ayat. Yang perlu digarisbawahi di sini, secara historis QS. al-Nisā'[4]: 141 dijelaskan Quraish sebagai gambaran sekilas tentang orang-orang munafiq yang menunggu kehancuran umat Islam dalam berperang. ${ }^{88}$ Menurut Hamka, ayat ini sebagai janji Allah untuk memberi kemenangan kepada umat Islam, yang sebelumnya umat Islam kalah dalam perang Uhud. ${ }^{89}$ Hasbi Ash-Shiddiqiey menjelaskan tentang orang munafiq memberikan bantuan atas kemenangan perang yang sangat berarti kepada orang-orang kafir. ${ }^{90}$ Maka pesan moral dalam ayat ini sebagai tuntunan kepada umat Islam untuk tetap beriman kepada Allah, jaminan yang diberikan Allah adalah wujud kemenangan atas peperangan dan tidak memberikan jalan kepada orang kafir untuk mengalahkan umat Islam dalam peperangan.

\section{Penutup}

Akhirnya dapat disimpulkan bahwa akibat kepentingan-kepentingan duniawi, termasuk kepentingan politik, dapat mempengaruhi pola pikir seseorang ketika berinteraksi dengan Alquran. Ayat-ayat Alquran pada akhirnya menjadi alat legitimasi dari kepentingan-kepentingan tersebut. Dalam penggunaan ayat-ayat Alquran dalam proses Pilkada DKI Jakarta menemukan ada tiga paradigma masyarakat yang berbeda dalam menafsirkan ayat-ayat Alquran, dalam hal ini terkait dengan kasus calon Gubernur Basuki Tjahaja Purnama (Ahok) yaitu: 1) menolak keras; 2) mendukung sepenuhnya; dan 3) tidak menampakkan diri dukungan ataupun penolakannya. Adanya pola pikir yang berbeda-beda inilah melahirkan penafsiran yang berbeda pula meski ayatnya sama.

\footnotetext{
${ }^{86} \mathrm{https}$ ://www.kompasiana.com/rize1924/hti-bersama-masyarakat-demotolakahok $57 \mathrm{cc} 06 \mathrm{c} 46423 \mathrm{bd} 824 \mathrm{cbadc} 68$

${ }^{87}$ Sahiron Syamsuddin, Hermeneutika dan Pengembangan Ulumul Qur'an, h. 46.

${ }^{88}$ M. Quraish Shihab, Tafsir al-Misbah, vol. 2, h. 601.

${ }^{89}$ Hamka, Tafsir al-Azhar, juz 5, h. 330.

90 TM. Hasbi Ash-Shiddieqy, Tafsir Alquranul Majid An-Nur, juz 2, h. 980.
} 


\section{DAFTAR PUSTAKA}

Afrizal, Lalu Heri. "Studi Kritik Atas Metodologi Tafsir Nașr Hamid Abū Zayd dan Dampaknya Terhadap Pemikiran Keagamaan", Makalah, Peserta Program Kaderisadi Ulama ISID Gontor angkatan VI., 2007.

Alhaddar, Muhsin Ali, Rasionalitas Penafsiran Sahabat dan Tabi'in "Kajian Atas Tafsir bi al-Mathur”, Ciputat: Isdar Press, 2012.

--------. "Unsur Politik dalam Dunia Penafsiran Alquran: Kasus-Kasus Penafsiran Sahabat dan Aliran Teologi Islam" Rausyan Fikr, Vol. 10, No. 2 Juli Desember, h. 221, 2014.

Anin, “ini Dia Pendapat Aa' Gym dan KH Said Aqil Siradj Terkait Pemimpin Non Muslim", diakses dari https://www.youtube.com/watch?v=mc6JrWF_pB0

Asa, Syu'bah. Dalam Cahaya Alquran: Tafsir Ayat-ayat Sosial Politik, Jakarta: PT Gramedia Pustaka Utama, 2000.

Bakar, Irfan Abu dan Bamualim, Chaider S. Modul, Resolusi Konflik Agama \& Etnis di Indonesia, Jakarta: Pusat Bahasa dan Budaya [PBB] UIN Syarif Hidayatullah Jakarta, 2006.

al-Dzahabī, Muhammad Ḥusein, Al-Ittijā-hāt al-Munḥarifah fî̀ Tafsìr al-Qur'ān alKarim, terj. Hamim Ilyas, Penyimpangan-penyimpangan dalam Penafsiran Alquran, Jakarta: PT. Raja Grafindo Persada, 1993.

Fata, Ahmad Khoirul. "M. Quraish Shihab dan Al-Maidah 51", Gorontalo Post, 9/11., 2016.

Gusmian, Islah, Khazanah Tafsir Indonesia; dari Hermeneutika hingga Ideologi, Yogyakarta: LkiS, 2013.

-------. "Tafsir Alquran Bahasa Jawa: Peneguh Identitas, Ideolog, dan Politik," Suhuf, Vol. 9, No. 1, Juni, h. 157-158, 2016.

Hanafi, Yusuf. "Pemikiran Politik dalam Tafsir Fath Al-Qadir: Pembacaana atas Konsep Ketatanegaraan dalam Alquran yang ditulis Al-Syaukānī”, Hemeneutik, Vol. 9, No. 2, Desember, 2015.

Herdiansah dkk., Ari Ganjar. "Pembelahan Ideologi, Kontestasi Pemilu, dan Persepsi Ancaman Keamanan Nasional: Spektrum Politik Indonesia Pasca 2014?" Jurnal Wacana Politik, Vol. 2, No. 1, Maret, 2017.

Hidayat, Hayat dan Hidayat, Moh., Sejarah Alquran dalam Pandangan Theodor Noldeke [1836-1930] dalam Mohammad Anwar Syarifuddin (ed.), Kajian Orientalis terhadap Alquran dan Hadits, Ciputat: CV Sakata Cendikia, 2015. 
188 Politik dan perubahan paradigma penafsiran ayat-ayat Alquran... - Lilik Ummi Kaltsum

Hitti, Philip K., History of The Arabs: From the Earliest Times to the Present, terj. R. Cecep Lukman Yasin dan Dedi Slamet Riyadi, Jakarta: PT Serambi Ilmu Semesta, 2008.

Husaini, Adian dan Al-Baghdadi. Abdurrahman, Hermeneutika \& Tafsir Alquran, Jakarta: Gema Insani, 2007.

Jinan, Mutohharun. "Relasi Ulama dan Umara dalam Sejarah Islam", Dirasah Islamiyah, Suara Muhammadiyah 04/96, 16-28 Februari, 2011.

Ma'sum, Khusnul Arifah. "Konsep Pemerintahan Menurut Bakri Syahid: Studi atas Tafsir Al-Huda Tafsir Qur'an Basa Jawi” (Skripsi: Jurusan Ilmu Alquran dan Tafsir Fakultas Ushuluddin dan Dakwah IAIN Surakarta), 2017.

Mustaqim, Abdul, Pergeseran Epistemologi Tafsir, Yogyakarta: Pustaka Pelajar, 2008.

Al-Munawar, Said Agil Husin, Dimensi-dimensi Kehidupan dalam Perspektif Islam, Malang: Pascasarjana Unisma, 2001.

Mustafa, Misbah Zainul. al-Iklil fi Ma'ani at-Tanzil, juz 20, Surabaya: Toko Kitab AlIhsan, Tth.

Penyusun, Tim. Kamus Besar Bahasa Indonesia, Jakarta: Balai Pustaka, 1990.

Rasil, Mimbar. "Habib M Rizieq Syihab - QS AlMaidah Ayat 51-52 Part 1" diakses dari https://www.youtube.com/watch?v=vdQSBjluIdc

Rhidho, Moch. Taufiq, "Analisis Metode Kontekstual Nașr Hamid Abū Zayd (ReInterpretasi atas Konsep Asbab Al-Nuzul)", Rasail, Vol. 1, No. 4, 2015.

Saeed, Abdullah, Interpreting the Qur'an: Towards a Contemporary Approach, London and New York: Routledge, 2006.

Syahdanul, Darul, Strategi Komuniti dalam Berpolitik, Universitas Indonesia, 2016.

Syahid, Bakri, al-Huda Tafsir Qur'an Basa Jawi, Yogyakarta: Bagus Arafah, 1983.

Shalahuddin, Henri, Alquran Dihujat, Jakarta: Al-Qalam, 2007.

Ash-Shiddieqy, M. Hasbi, Tafsir Alquran Al-Majid An-Nur, Semarang: Pustaka Rizki Putra, 2000.

Shihab, M. Quraish, Membumikan Alquran: Fungsi dan Peran Wahyu dalam Kehidupan Masyarakat, Bandung: Mizan, 1995.

Wawasan Alquran: Tafsir Maudhu'i atas Pelbagai Persoalan Umat, Bandung: Mizan, 2000.

Alquran dan Maknanya, Jakarta: Lentera Hati, 2010. 
Shihab, Habib M. Rizieq bin Husain, Dialog FPI Amar Ma'ruf Nahi Munkar: Menjawab berbagai Tuduhan terhadap Gerakan Nasional Anti Ma'siat di Indonesia, Jakarta: Pustaka Ibnu Sidah, 2004.

Syamsuddin, Sahiron, Hermeneutika dan Pengembangan Ulumul Qur'an, Yogyakarta: Pesantren Nawesea Press, 2009.

-------. “Ma'na-cum-maghza Approach to the Qur'an: Interpretaton of Q. 5: 51”, Atlantis Press, Proceedings of the International Conference on Qur'an and Hadith Studies (ICQHS 2017), Vol. 137, 2018

-------. "Penafsiran Kontekstual atas QS. al-Ma'dah 51”, diakses dari http://uinsuka.ac.id/v2016/kolom/detail/52/penafsiran-kontekstualis-atas-qs-al-maidah-51 atau lihat http://aiat.or.id/2017/10/28/penafsiran-kontekstualis-atas-q-s-al-maidah-51/

Suryadinata, M., "Non Muslim dalam Alquran: Analisis terhadap Penafsiran FPI Mengenai Ayat Pemimpin Non Muslim”, Ilmu Ushuluddin, Volume 2, Nomor 2, Januari-Juni, 2015.

Wijaya, Aksin, Teori Interpretasi Alquran Ibnu Rusyd: Kritik Ideologis-Hermeneutika, Yogyakarta: LkiS, 2009.

--------. Satu Islam Ragam Epistemologi: Dari Epistemologi Teosentrisme ke Antroposentrisme, Yogyakarta: Pustaka Pelajar, 2014.

Yunus, Mahmud, Kamus Arab-Indonesia, Jakarta: PT. Hidakarya Agung, th.

Zamzami, Mohammad Subhan, "Tafsir Ideologis dalam Khazanah Intelektual Islam," Mutawatir: Jurnal Keilmuan Tafsir Hadis, Volume 4, Nomor 1, Juni, 2014.

Zayd, Nașr Hamid Abū, Mafhum al-Nās Dirasah fì 'Ulūm al-Qur'ān, terj. Khoirun Nahdliyyin, Tekstualitas Alquran: Kritik terhadap Ulum Alquran, Yogyakarta: LkiS, 2005.

Zuhri, Jamaluddin. Athur Jeffery dan Kajian Sejarah Teks Alquran dalam Mohammad Anwar Syarifuddin (ed.), Kajian Orientalis terhadap Alquran dan Hadits, Ciputat: CV Sakata Cendikia. 